\title{
Plasma deposition of organic polymer films for solar cell applications
}

Wallace W. H. Wong, * Sam Rudd, Kola Ostrikov, Melanie Ramiasa-MacGregor, Jegadesan Subbiah, Krasimir Vasilev*

Dr. J. Subbiah, Dr. W. W. H. Wong

School of Chemistry, University of Melbourne Bio21 Institute, 30 Flemington Rd, Parkville, Victoria 3010, Australia.

S. Rudd, K. Ostrikov, M. Ramiasa-MacGregor, Prof. K. Vasilev

Mawson Institute, University of South Australia, Mawson Lakes Campus, Mawson Lakes

Boulevard, Mawson Lakes, South Australia 5095, Australia.

E-mail: wwhwong@unimelb.edu.au, Krasimir.Vasilev@unisa.edu.au.

Keywords: plasma deposition, organic interlayer, organic solar cells

\begin{abstract}
The use of plasma deposited organic thin films as the interlayer component in organic solar cells applications is demonstrated for the first time. Up to $20 \%$ increase in solar cell device performance was observed when an interlayer deposited from the vapor of 4-methylthiazole was used. This work demonstrates the potential of plasma deposition of organic films to be integrated in fabrication of organic solar cells with superior properties.
\end{abstract}

\section{Introduction}

Controlling and tuning the properties of interfaces in semiconducting devices is essential to achieve high performance and stability.[1-5] The physical as well as electronic contact between electrode materials and the active semiconducting components of devices must be appropriately aligned. Interlayer materials are often used to achieve the desired outcome by changing the physical properties of surfaces.[5] Properties including surface roughness, surface energy (i.e. hydrophobicity and hydrophilicity) and workfunction can be tuned to attain intimate physical and electronic contact between various device layers.[6, 7] In organic solar cells, interlayers can also selectively block charges[3, 8] and affect the molecular order of the thin films[9] resulting in improved device performance. There are several types of interlayers currently in 
use in organic solar cells.[1, 10] One of the more interesting example is the use of polyethylenimine (PEI) as workfunction modifying interlayers in organic electronic devices.[11] The workfunction of a number of metal oxides and metals can be changed by applying a thin layer of the polymer on the surface. This resulted in better electronic contact between the electrode material and the active semiconducting materials. This work inspired us to examine thin polymer layers deposited by plasma deposition for application in interface modification.

Plasma deposition of organic films has become a hot topic of investigation to produce functional coatings for a variety of applications including antibaterial films and nanocapsules for drug delivery.[12-14] Plasma deposition is an attractive process because it is solvent-free, the process is independent of substrate and generates smooth pinhole-free films with good adhesion properties (Figure 1a).[15] It is important to note here that plasma deposition of organic materials is significantly different to most deposition techniques (e.g. spin coating, splutter coating, chemical vapour deposition, etc.) because chemical reaction occurs in the plasma leading to chemical bonding and crosslinking of precursor molecules to form polymeric films. There are only a few studies in the literature that used plasma deposited polymeric materials for electronic applications.[16-21] The majority of these studies were focused on the conducting properties of doped films. Investigations into semiconducting properties of plasma deposited organic films has been rare.[19] For this reason, we were encouraged to explore the possibility of generating organic films by plasma deposition in semiconducting device applications. The use of plasma as a deposition method in organic semiconducting devices have the added advantage of process simplification. This is because the deposition process can be blended with one of the most commonly applied process in the fabrication of organic electronic devices which is the oxygen plasma cleaning of the inorganic device substrate. It is envisaged that the device fabrication process will be simplified if the interlayer film can be deposited directly after the oxygen plasma cleaning in the same plasma chamber. Furthermore, organic 
films deposited from plasma typically have strong bonding to the substrate which is expected to benefit device performance.

(a)

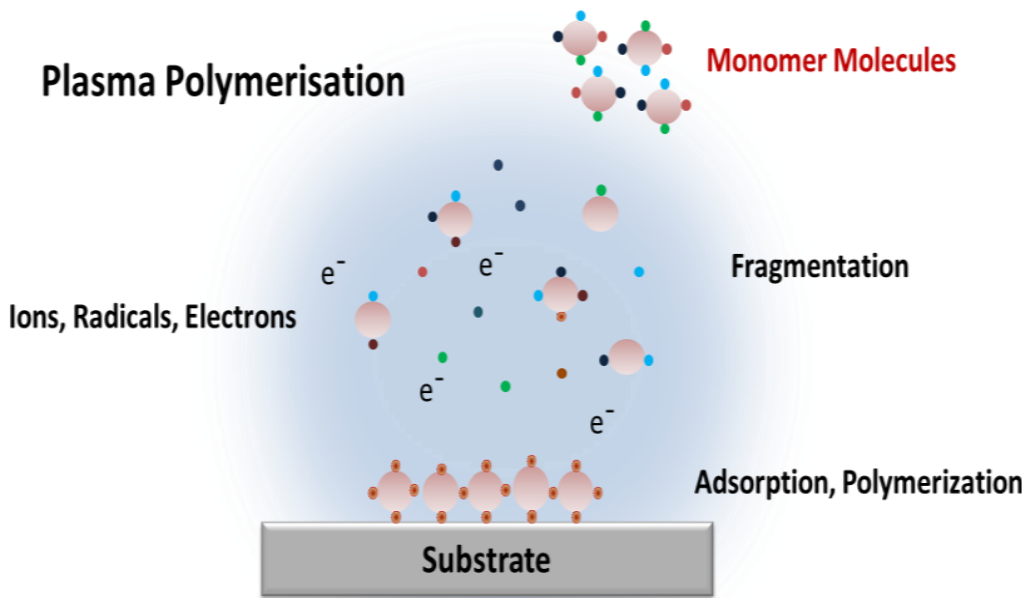

(b) Gage Pressure

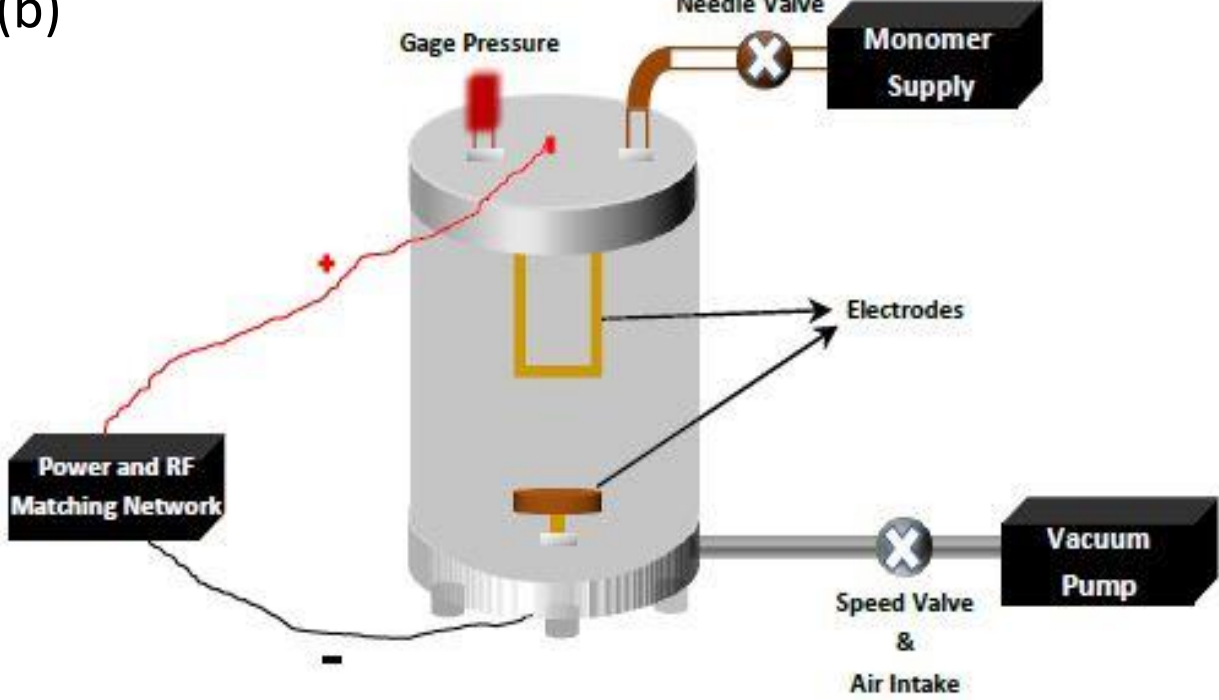

Figure 1. (a) Illustration of the plasma deposition process and (b) representation of the plasma deposition experiment setup.

\section{Results and Discussion}

To begin with, four organic precursors was selected for plasma deposition. These included thiophene, 4-methylthiazole, allylamine and heptylamine. Thiophene was chosen as one of the organic precursors because it was examined previously in conductivity measurements after doping.[18, 19] However, in these cases, plasma deposition of thiophene produced films that were partially oxidized and highly crosslinked. 4-Methylthiazole was chosen as a nitrogen- 
containing analogue of thiophene while allylamine and heptylamine would potentially result in polymer structures similar to these proven to be beneficial as interlayers, as recently published.[11]

To deposit plasma polymerised films, deposition was carried out in Continuous Wave (CW) mode. The samples were placed in the parallel plate plasma chamber (Figure 1b, see SI for details on substrate preparation). The reactor was evacuated to $1 \times 10^{-2}$ mbar and oxygen plasma was applied using power of $50 \mathrm{~W}$ at pressure of $1.1 \times 10^{-1} \mathrm{mbar}$ for $1 \mathrm{~min}$. The reactor was then again evacuated to base pressure. Then, the precursors were introduced into the chamber with a selected flow rate by a needle valve. A radio frequency $(13.56 \mathrm{MHz})$ generator was used to deliver RF power in the range of $1-50 \mathrm{~W}$ via the electrode in the reactor chamber in order to create low temperature plasma. A pulse generator (TTi) and a digital storage oscilloscope (Tektronix, TDS 2024) were added to the power generator circuit to provide the plasma in pulsed mode. In the plasma polymerisation process, the RF powers and the time of the polymerisation were carefully adjusted to achieve appropriate film thicknesses.

The precision in film thickness control (from $2 \mathrm{~nm}$ to $>50 \mathrm{~nm}$ ) is important in the application of these films in organic electronic devices. The sample thicknesses were measured by ellipsometry (see SI for experimental details). The deposition conditions were selected in a manner that plasma polymer film thickness increased linearly with deposition time for all precursors used. Figure 2a shows a typical example of thickness growth vs time during deposition of thiophene (data for other monomers can be found in the SI, Figure S2-S5). Once film thicknesses were determined, the photophysical properties and composition of the films were investigated. The UV-Vis absorption spectrum of the films were recorded (see SI for data on all films, Figure S7-S10). For the thiophene and 4-methylthiazole samples, the absorption onset was at $400 \mathrm{~nm}$ (Figure $2 \mathrm{~b}$ and S8). This was a clear indication that there is a low degree of $\pi$-conjugation in the films as observed in previous studies with thiophene.[19] While this 
was obviously an undesirable outcome in terms of achieving semiconducting organic films, these materials can be used as thin interfacial components in solar cell devices.[1, 11] It is important to note that plasma deposited films with thickness greater than $10 \mathrm{~nm}$ behave as electrically insulating films.
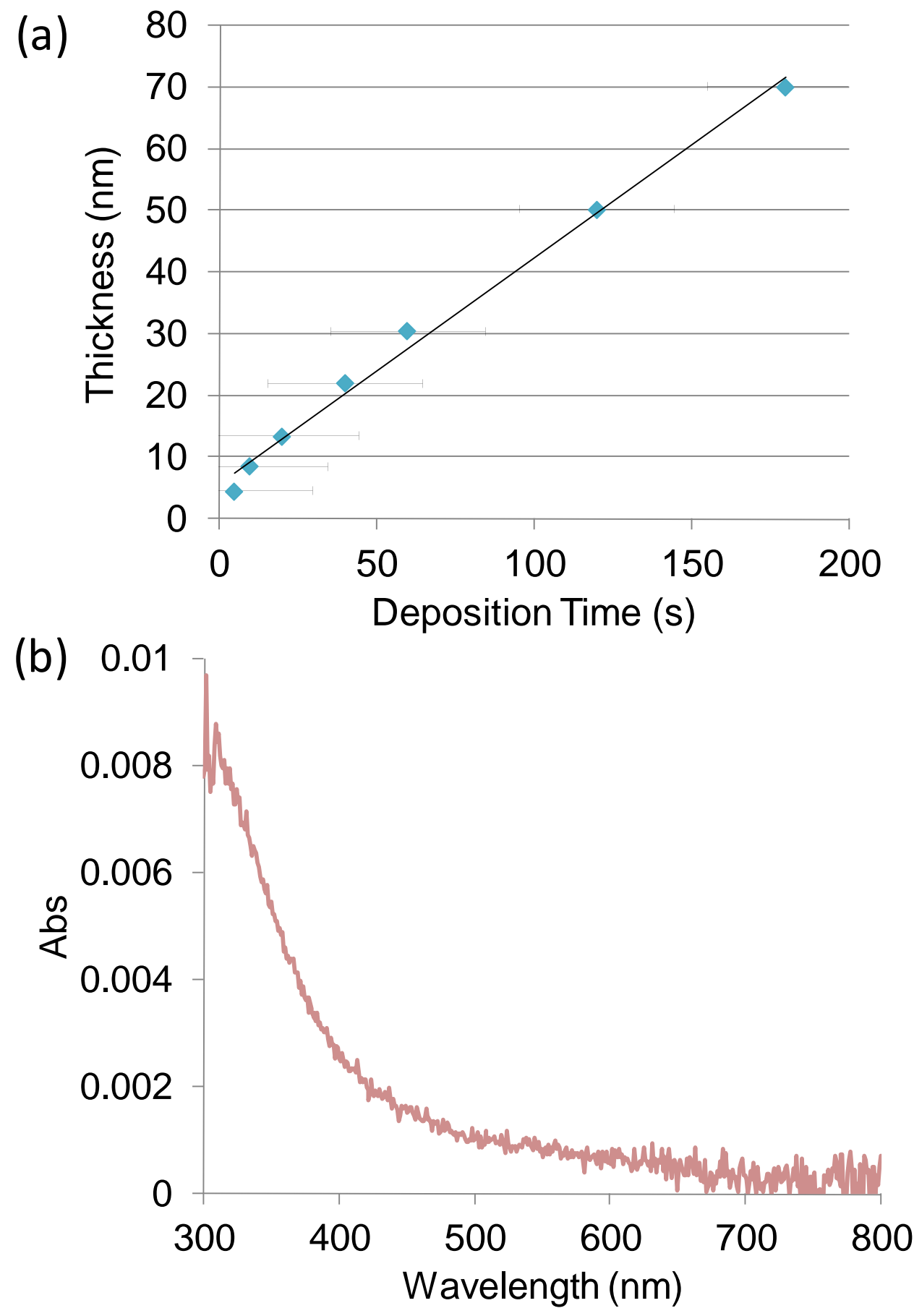

Figure 2. (a) Plot showing the linear relationship between deposition time and film thickness for the thiophene deposition and (b) the UV-Vis absorption spectrum of the thiophene film ( 5 nm thick). 
X-ray photoelectron spectroscopy (XPS) was used to examine their elemental composition of the plasma deposited films (Figure 3). Table 1 shows the calculated elemental content of the films from the XPS data. It would be reasonable to expect that the ratio of elemental composition of the monomer precursor and that of the films to be similar if there was a high degree of structural retention. This is an important consideration for the thiophene and 4-methylthiazole films as high structural retention is related to the degree of $\pi$-conjugation in the polymerized films and therefore their semiconducting properties. However, the elemental ratio $(\mathrm{C}: \mathrm{S})$ was different for the precursors and the generated films (Table 1). In addition, the high oxygen content in all films was indicative of oxidation of the organic films during plasma deposition. These results are not surprising since it is well-know that plasma deposition leads to organic coatings that are very different in composition and structure compared to films deposited using conventional polymerization methods. The precursors are typically fragmented to various degrees and the resulting coating has higher level of crosslinking. The elemental composition of the thiophene coating is consistent with published studies.[19] 


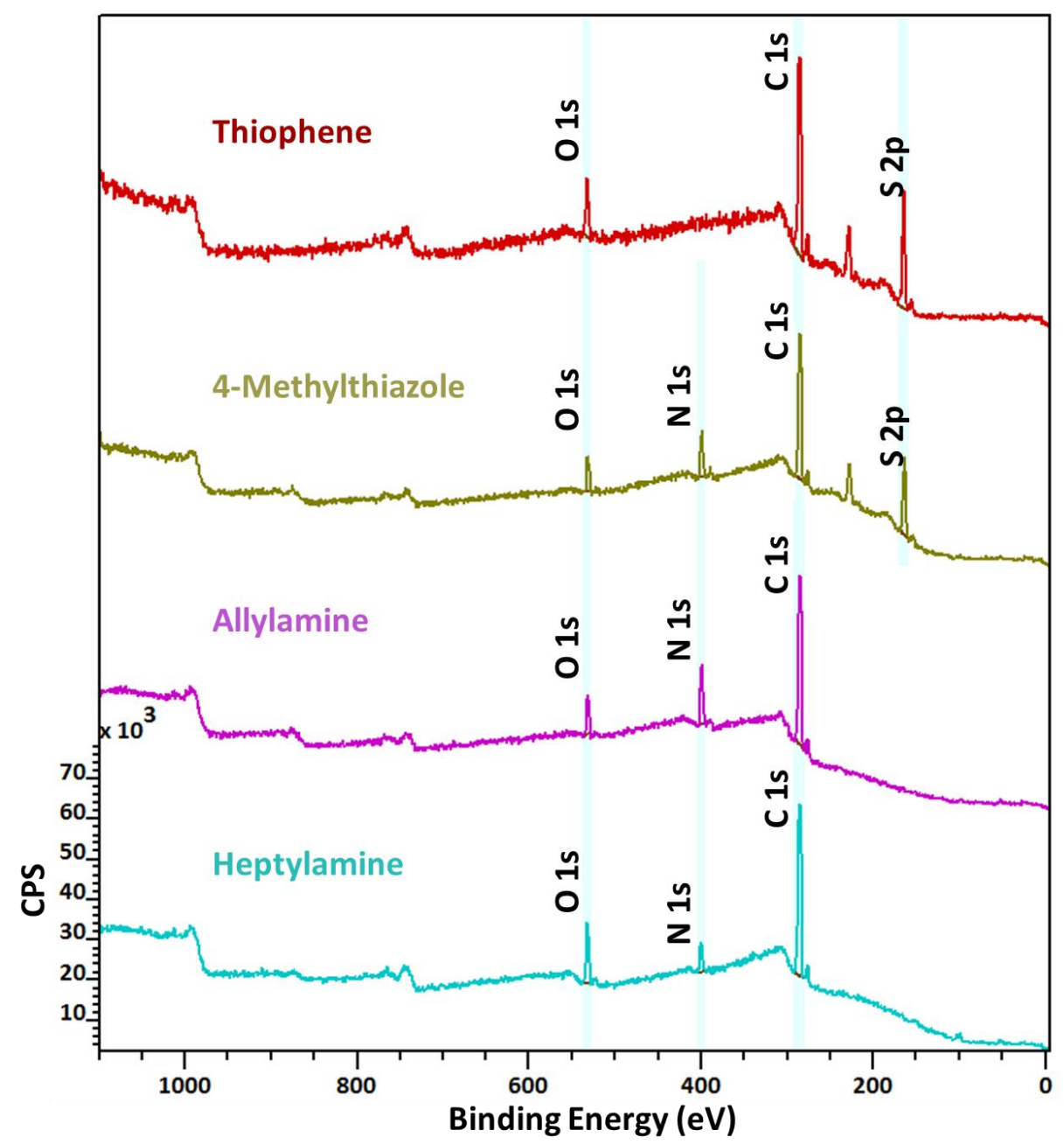

Figure 3. XPS spectrum of plasma deposited organic films.

Table 1. Elemental composition of the films calculated from XPS data.

\begin{tabular}{|c|c|c|c|c|c|c|}
\hline \multirow{2}{*}{ Entry } & \multirow{2}{*}{ Monomers } & \multicolumn{4}{|c|}{ Elemental composition \%a } & \multirow{2}{*}{ C:S $b$} \\
\cline { 3 - 6 } & \multirow{2}{*}{1} & $\mathrm{C}$ & $\mathrm{S}$ & $\mathrm{N}$ & $\mathrm{O}$ & \\
\hline \multirow{2}{*}{2} & \multirow{2}{*}{ Thiophene } & $\begin{array}{c}70 \\
(57)\end{array}$ & $\begin{array}{c}23 \\
(38)\end{array}$ & - & 7 & 3.1 \\
& \multirow{2}{*}{$4-$ Methylthiazole } & $\begin{array}{c}64 \\
(49)\end{array}$ & $\begin{array}{c}20 \\
(32)\end{array}$ & $\begin{array}{c}11 \\
(14)\end{array}$ & $\begin{array}{c}5 \\
(-)\end{array}$ & $\begin{array}{c}3.2 \\
(1.5)\end{array}$ \\
\hline \multirow{2}{*}{3} & Allylamine & $\begin{array}{c}79 \\
(63)\end{array}$ & - & $\begin{array}{c}15 \\
(25)\end{array}$ & $\begin{array}{c}6 \\
(-)\end{array}$ & - \\
\hline \multirow{2}{*}{4} & \multirow{2}{*}{ Heptylamine } & $\begin{array}{c}81 \\
(73)\end{array}$ & - & $\begin{array}{c}8 \\
(12)\end{array}$ & $\begin{array}{c}11 \\
(-)\end{array}$ & - \\
\hline
\end{tabular}

${ }^{a}$ Elemental composition of the plasma deposited films with the values for the precursors in brackets; ${ }^{\mathrm{b}}$ ratio of carbon to sulphur in the films and the $\mathrm{C}: \mathrm{S}$ value for the precursor in brackets. 
The molecular structure of the films were examined by FTIR analysis. Consistent with the XPS studies, all films showed a broad $-\mathrm{OH}$ stretching band in the $3200 \mathrm{~cm}^{-1}$ region and a strong $\mathrm{C}=\mathrm{O}$ band at $1640 \mathrm{~cm}^{-1}$ indicating oxygen incorporation in the plasma deposition process (Figure S6). Apart from $\mathrm{C}-\mathrm{H} \mathrm{sp} \mathrm{s}^{3}$ stretches and bending vibrations evident in all samples, films deposited with the allylamine precursor[22] showed a $\mathrm{C} \equiv \mathrm{N}$ stretch at $2200 \mathrm{~cm}^{-1}$ while 4methylthiazole films showed $\mathrm{C} \equiv \mathrm{N}$ stretch at $2200 \mathrm{~cm}^{-1}$ and $\mathrm{C} \equiv \mathrm{C}$ stretch at $2070 \mathrm{~cm}^{-1}$. Detailed analysis of the FTIR spectra can be found in the supporting information (Table S3). The FTIR data provided further evidence that the retention of precursor molecule structure is low in the resulting plasma deposited films with substantial oxidation of the organic material. Atomic force microscopy (AFM) was used to probe the surface of the plasma deposited films. All films were very smooth $(\mathrm{RMS}$ roughness $=0.2 \mathrm{~nm}$ ) and pinhole free (see SI for AFM images, Figure S11).

With data on the physical properties of the polymer films in hand, the next part of the study involved the use of these plasma deposited films in organic solar cell devices. The elemental composition from XPS experiments indicated incorporation of oxygen atoms (5 to $10 \%$ ) in the organic films (Table 1). Combining this with the UV-Vis absorption data, it was reasonable to suggest that the chemical structure of the organic precursors was substantially modified into a crosslinked and partially oxidised polymer film.[19, 20, 23] Although such films is normally a poor platform for a semiconducting material, polymers with similar sturctures, such as polyethylenimine ethoxylated (PEIE), has been successfully employed as interlayer components in organic electronic devices.[11] For this reason, it was decided that these plasma deposited organic films would be tested as interlayer materials in bulk heterojunction (BHJ) solar cells.

A device architecture of ITO/ZnO (25 nm)/plasma film (5 nm)/active layer/MoO3 (10 $\mathrm{nm}) / \mathrm{Ag}(100 \mathrm{~nm})$ was used as shown in the Figure 4(a). The $\mathrm{ZnO}$ nanoparticle layer was depsoited by spin coating onto ITO on glass substrate.[24] The plasma film was deposited in a 
plasma reactor chamber using the optimized conditions described above to achieve controlled film thickness. The active layer $(\sim 145 \mathrm{~nm})$ consisted of a blend of poly(3-hexylthiophene) $\mathrm{P} 3 \mathrm{HT}$ and $\mathrm{PC}_{61} \mathrm{BM}$ in a weight ratio of 1:1 deposited by spin coating from 1,2-dichlorobenzene solution (see SI for details on device fabrication). Figure 4 (b) shows current density vs. voltage characteristics of devices containing various interlayer materials and. Table 2 summarizes the performance characteristics of solar cell devices under AM 1.5G simulated illumination with an intensity of $100 \mathrm{~mW} / \mathrm{cm}^{2}$. The performance of the solar cells with various plasma deposited interlayers was compared with the solar cell without plasma interlayer using $\mathrm{P} 3 \mathrm{HT}: \mathrm{PC}_{61} \mathrm{BM}$ blend as the active layer. The polymer solar cell with plasma deposited 4-methylthiazole layer shows the best performance with a PCE of $3.6 \%$, a short-circuit current density $\left(\mathrm{J}_{\mathrm{sc}}\right)$ of 9.2 $\mathrm{mA} / \mathrm{cm}^{2}$, an open-circuit voltage $\left(\mathrm{V}_{\mathrm{oc}}\right)$ of $0.62 \mathrm{~V}$ and a fill factor (FF) of 0.63 . Devices containing only the $\mathrm{ZnO}$ layer showed maximum PCE of $3.1 \%$ which was comparable with previously reported devices using the $\mathrm{P} 3 \mathrm{HT} / \mathrm{PC}_{61} \mathrm{BM}$ active layer system.[25, 26] It is noteworthy that devices examined in this work were handled in air. 
(a)

\begin{tabular}{|c|}
\hline \multicolumn{1}{|c|}{$\mathrm{Ag}(100 \mathrm{~nm})$} \\
\hline $\mathrm{MoO}_{3}(10 \mathrm{~nm})$ \\
\hline $\mathrm{P} 3 \mathrm{HT} / \mathrm{PC}_{61} \mathrm{BM} 1: 1$ \\
$(145 \mathrm{~nm})$ \\
\hline Plasma layer $(5 \mathrm{~nm})$ \\
\hline $\mathrm{ZnO}(25 \mathrm{~nm})$ \\
\hline ITO \\
\hline Glass substrate \\
\hline
\end{tabular}

(b)

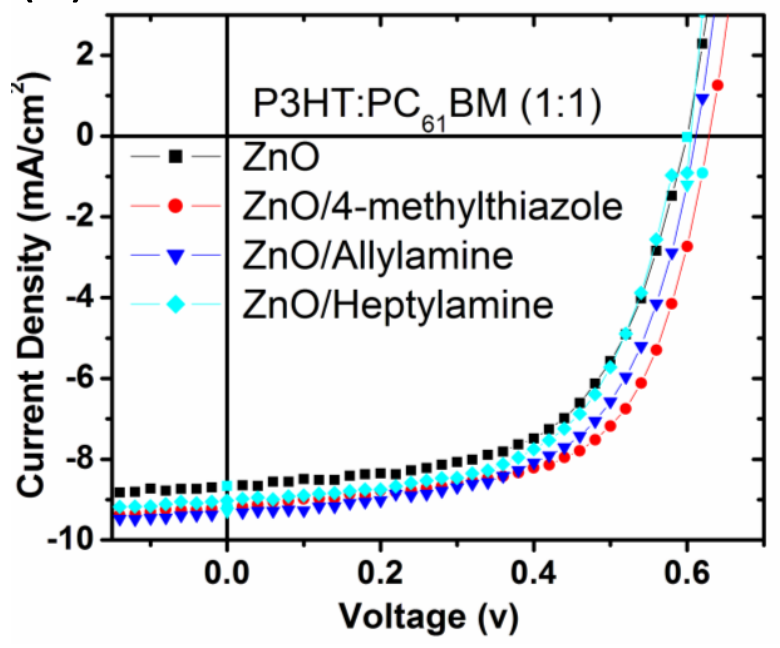

Figure 4. (a) BHJ solar cell device geometry and (b) J-V characteristics of devices containing various plasma deposited layers.

Table 2. Photovoltaic device performance of inverted BHJ solar cells. Average was obtained from over ten devices tested and highest device performance in parenthesis.

\begin{tabular}{|c|c|c|c|c|c|c|}
\hline Interlayer & $\begin{array}{c}\mathrm{J}_{\mathrm{sc}} \\
\left(\mathrm{mA} / \mathrm{cm}^{2}\right)\end{array}$ & $\begin{array}{c}V_{\mathrm{oc}} \\
(\mathrm{V})\end{array}$ & $\begin{array}{c}F F \\
(\%)\end{array}$ & $\begin{array}{c}\mathrm{PCE} \\
(\%)\end{array}$ & $\begin{array}{c}\mathrm{R}_{\mathrm{s}} \\
\left(\Omega \mathrm{cm}^{2}\right)\end{array}$ & $\begin{array}{c}\mathrm{R}_{\mathrm{sh}} \\
\left(\Omega \mathrm{cm}^{2}\right)\end{array}$ \\
\hline $\mathrm{ZnO}$ & $8.4 \pm 0.2$ & $\begin{array}{c}0.60 \\
\pm 0.01\end{array}$ & $58 \pm 2$ & $\begin{array}{c}2.85 \pm 0.25 \\
(3.1)\end{array}$ & 13.9 & 565 \\
\hline $\begin{array}{c}\mathrm{ZnO} / 4- \\
\text { methylthiazole }\end{array}$ & $8.9 \pm 0.3$ & $\begin{array}{c}0.62 \\
\pm 0.01\end{array}$ & $61 \pm 3$ & $\begin{array}{c}3.40 \pm 0.20 \\
(3.6)\end{array}$ & 8.6 & 835 \\
\hline ZnO/allylamine & $9.0 \pm 0.2$ & $\begin{array}{c}0.61 \\
\pm 0.01\end{array}$ & $61 \pm 2$ & $\begin{array}{c}3.25 \pm 0.15 \\
(3.4)\end{array}$ & 8.9 & 909 \\
\hline ZnO/heptylamine & $8.8 \pm 0.2$ & $\begin{array}{c}0.58 \\
\pm 0.02\end{array}$ & $60 \pm 1$ & $\begin{array}{c}3.10 \pm 0.20 \\
(3.3)\end{array}$ & 10.5 & 990 \\
\hline
\end{tabular}


The improved PCE of devices with the 4-methylthiazole interlayer was a result of increased short-circuit current and fill factor. It has been reported that a thin interlayer or self assembled monolayer (SAM) significantly improve electrical contact, adhesion and charge transfer properties of various metal oxides surfaces. $[10,27]$ In the case of the plasma deposited organic films on $\mathrm{ZnO}$, the surface roughness was reduced for the plasma coated samples compared to the $\mathrm{ZnO}$ only sample (Figure $\mathrm{S} 12)$. The calculated series resistance $\left(\mathrm{R}_{\mathrm{s}}\right)$ and shunt resistance $\left(\mathrm{R}_{\mathrm{sh}}\right)$ from the current/voltage device data showed that $\mathrm{R}_{\mathrm{s}}$ is reduced and $\mathrm{R}_{\text {sh }}$ increased when plasma films were used (Table 2). This enhanced electric contact in the device can be attributed to the passivation of metal oxide surface trap states and it leads to the suppression of recombination at the interface.[28-30] Further to surface passivation, the amine group in the interlayer material can have favorable dipole alignment at the interface which leads to the efficient charge extraction and hence the enhancement in the OPV device performance.[11, 31] Interestingly, films made using thiophene as the organic precursor gave poor performing devices with PCE of $\sim 0.1 \%$ (Figure $\mathrm{S} 13$ ). While the $\mathrm{V}_{\text {oc }}$ was as expected for P3HT/PC 61 BM devices, the $\mathbf{J}_{\mathrm{sc}}$ and FF were very low. It would appear that photo-generated electrons are strongly recombining in the plasma layer with thiophene precursor compared to nitrogencontaining precursors.

\section{Conclusion}

In conclusion, a series of organic polymer films were produced by plasma deposition of small molecule precursors containing sulphur and nitrogen atoms. While the initial aim was to target films with semiconducting properties, it was found that ultra-thin layers of these plasma deposited films can be used as interlayer materials in organic solar cell devices. Performance enhancement was observed for devices with films deposited from nitrogen-containing precursors. With the increasing importance of interface engineering, the method developed in this work may find applicability in a variety of flexible electronic devices. 


\section{Supporting Information}

Details on the plasma film deposition procedure and characterization of the materials as well as device fabrication and testing can be found in the Supporting Information.

\section{Acknowledgements}

This work was partly supported by funds from the Australian Renewable Energy Agency through the Australian Centre for Advanced Photovoltaics. WWHW and KV are supported by Australian Research Council Future Fellowships (FT130100500, FT100100292). Responsibility for the views, information, or advice herein is not accepted by the Australian Government.

\section{References}

[1] C.-C. Chueh, C.-Z. Li, A.K.Y. Jen, Recent progress and perspective in solution-processed Interfacial materials for efficient and stable polymer and organometal perovskite solar cells, Energy Environ. Sci., 8 (2015) 1160-1189.

[2] T.-H. Lai, S.-W. Tsang, J.R. Manders, S. Chen, F. So, Properties of interlayer for organic photovoltaics, Mater. Today, 16 (2013) 424-432.

[3] E.L. Ratcliff, B. Zacher, N.R. Armstrong, Selective Interlayers and Contacts in Organic Photovoltaic Cells, J. Phys. Chem. Lett., 2 (2011) 1337-1350.

[4] L.-M. Chen, Z. Xu, Z. Hong, Y. Yang, Interface investigation and engineering - achieving high performance polymer photovoltaic devices, J. Mater. Chem., 20 (2010) 2575-2598.

[5] J.H. Park, T.-W. Lee, B.-D. Chin, D.H. Wang, O.O. Park, Roles of Interlayers in Efficient Organic Photovoltaic Devices, Macromol. Rapid Commun., 31 (2010) 2095-2108.

[6] R.B. Ambade, S.B. Ambade, R.S. Mane, S.-H. Lee, Interfacial Engineering Importance of Bilayered $\mathrm{ZnO}$ Cathode Buffer on the Photovoltaic Performance of Inverted Organic Solar Cells, ACS Appl. Mater. Interfaces, 7 (2015) 7951-7960.

[7] Y. Zhang, L. Chen, X. Hu, L. Zhang, Y. Chen, Low Work-function Poly(3,4ethylenedioxylenethiophene): Poly(styrene sulfonate) as Electron-transport Layer for Highefficient and Stable Polymer Solar Cells, Sci. Rep., 5 (2015) 12839.

[8] J.M. Ren, J. Subbiah, B. Zhang, K. Ishitake, K. Satoh, M. Kamigaito, G.G. Qiao, E.H.H. Wong, W.W.H. Wong, Fullerene peapod nanoparticles as an organic semiconductor-electrode interface layer, Chem. Commun., (2016) DOI: 10.1039/C1035CC10444K.

[9] H.H. Dam, K. Sun, E. Hanssen, J.M. White, T. Marszalek, W. Pisula, J. Czolk, J. Ludwig, A. Colsmann, M. Pfaff, D. Gerthsen, W.W.H. Wong, D.J. Jones, Morphology Change and Improved Efficiency in Organic Photovoltaics via Hexa-peri-hexabenzocoronene Templates, ACS Appl. Mater. Interfaces, 6 (2014) 8824-8835.

[10] H.-L. Yip, A.K.Y. Jen, Recent advances in solution-processed interfacial materials for efficient and stable polymer solar cells, Energy Environ. Sci., 5 (2012) 5994-6011. 
[11] Y. Zhou, C. Fuentes-Hernandez, J. Shim, J. Meyer, A.J. Giordano, H. Li, P. Winget, T. Papadopoulos, H. Cheun, J. Kim, M. Fenoll, A. Dindar, W. Haske, E. Najafabadi, T.M. Khan, H. Sojoudi, S. Barlow, S. Graham, J.-L. Brédas, S.R. Marder, A. Kahn, B. Kippelen, A Universal Method to Produce Low-Work Function Electrodes for Organic Electronics, Science, 336 (2012) 327-332.

[12] A. Cavallaro, K. Vasilev, Controlled and sustained release of pharmaceuticals via single step solvent-free encapsulation, Chem. Commun., 51 (2015) 1838-1841.

[13] K. Vasilev, Nanoengineered Plasma Polymer Films for Biomaterial Applications, Plasma Chem. Plasma Process., 34 (2014) 545-558.

[14] K. Vasilev, S.S. Griesser, H.J. Griesser, Antibacterial Surfaces and Coatings Produced by Plasma Techniques, Plasma Processes Polym., 8 (2011) 1010-1023.

[15] K. Vasilev, A. Michelmore, H.J. Griesser, R.D. Short, Substrate influence on the initial growth phase of plasma-deposited polymer films, Chem. Commun., (2009) 3600-3602.

[16] B. Paosawatyanyong, P. Kamphiranon, W. Bannarakkul, Y. Srithana-anant, W. Bhanthumnavin, Doping of polythiophene by microwave plasma deposition, Surf. Coat. Technol., 204 (2010) 3053-3058.

[17] H. Goktas, F.G. Ince, Characterization of Plasma-Polymerized Thiophene Thin Films and Nanoparticles Synthesized by a Double-Discharge Technique, Plasma Processes Polym., 6 (2009) 126-131.

[18] T.-W. Kim, J.-H. Lee, J.-W. Back, W.-G. Jung, J.-Y. Kim, Deposition and in-situ plasma doping of plasma-polymerized thiophene films using PECVD, Macromol. Res., 17 (2009) 3136.

[19] R. Dams, D. Vangeneugden, D. Vanderzande, Plasma Deposition of Thiophene Derivatives Under Atmospheric Pressure, Chem. Vap. Deposition, 12 (2006) 719-727.

[20] A. Kiesow, A. Heilmann, Deposition and properties of plasma polymer films made from thiophenes, Thin Solid Films, 343-344 (1999) 338-341.

[21] R.K. Sadhir, K.F. Schoch, Preparation and properties of plasma-polymerized thiophene (PPT) conducting films, Thin Solid Films, 223 (1993) 154-160.

[22] V. Krishnamurthy, I.L. Kamel, Y. Wei, Analysis of plasma polymerization of allylamine by FTIR, J. Polym. Sci., Part A: Polym. Chem., 27 (1989) 1211-1224.

[23] T. Teslaru, I. Topala, M. Dobromir, V. Pohoata, L. Curecheriu, N. Dumitrascu, Polythiophene films obtained by polymerization under atmospheric pressure plasma conditions, Mater. Chem. Phys., 169 (2016) 120-127.

[24] G. Sarasqueta, K.R. Choudhury, J. Subbiah, F. So, Organic and Inorganic Blocking Layers for Solution-Processed Colloidal PbSe Nanocrystal Infrared Photodetectors, Adv. Funct. Mater., 21 (2011) 167-171.

[25] M.T. Dang, L. Hirsch, G. Wantz, P3HT:PCBM, Best Seller in Polymer Photovoltaic Research, Adv. Mater., 23 (2011) 3597-3602.

[26] C.J. Brabec, S. Gowrisanker, J.J.M. Halls, D. Laird, S.J. Jia, S.P. Williams, PolymerFullerene Bulk-Heterojunction Solar Cells, Adv. Mater., 22 (2010) 3839-3856.

[27] J. Subbiah, B. Purushothaman, M. Chen, T. Qin, M. Gao, D. Vak, F.H. Scholes, X. Chen, S.E. Watkins, G.J. Wilson, A.B. Holmes, W.W.H. Wong, D.J. Jones, Organic Solar Cells Using a High-Molecular-Weight Benzodithiophene-Benzothiadiazole Copolymer with an Efficiency of 9.4\%, Adv. Mater., 27 (2015) 702-705. 
[28] J.W. Jung, J.W. Jo, W.H. Jo, Enhanced Performance and Air Stability of Polymer Solar Cells by Formation of a Self-Assembled Buffer Layer from Fullerene-End-Capped

Poly(ethylene glycol), Adv. Mater., 23 (2011) 1782-1787.

[29] Y.E. Ha, M.Y. Jo, J. Park, Y.-C. Kang, S.I. Yoo, J.H. Kim, Inverted Type Polymer Solar Cells with Self-Assembled Monolayer Treated ZnO, J. Phys. Chem. C, 117 (2013) 26462652.

[30] S.K. Hau, Y.-J. Cheng, H.-L. Yip, Y. Zhang, H. Ma, A.K.Y. Jen, Effect of Chemical Modification of Fullerene-Based Self-Assembled Monolayers on the Performance of Inverted Polymer Solar Cells, ACS Appl. Mater. Interfaces, 2 (2010) 1892-1902.

[31] S. Liu, K. Zhang, J. Lu, J. Zhang, H.-L. Yip, F. Huang, Y. Cao, High-Efficiency Polymer Solar Cells via the Incorporation of an Amino-Functionalized Conjugated Metallopolymer as a Cathode Interlayer, J. Am. Chem. Soc., 135 (2013) 15326-15329. 